УДК 622.833

DOI: https://doi.org/10.26642/ten-2020-2(86)-171-178

С.Г. Негрій, к.т.н., доц.

ДВНЗ «Донецький національний технічний університет»

\title{
Дослідження особливостей процесу передачі навантажень в конструкції з рядової породи
}

\begin{abstract}
Обгрунтовано необхідність подальшої розробки або вдосконалення засобів охорони на основі використання рядової породи зі спечіальними конструктивними особливостями для ефективного підтримання підготовчих виробок позаду очисних вибоїв під час видобутку вугілля підземним способом в умовах шахт украӥнського Донбасу. Розглянуто механізм формування вантажонесучих породних конструкцій, а також проаналізовано фактори, щзо впливають на їх стійкість, та встановлено найбільш впливові з них. Для визначення раціональних параметрів зазначених конструкиій здійснено аналітичні дослідження щуодо вивчення особливостей передачі навантажень у породних конструкціях. Для изього було запропоновано аналітичні моделі щзодо складання рівнянь граничної рівноваги елементарних об'ємів по висоті та ширині породної насипки з бічним опором. Вирішення диференціальних рівнянь дозволило встановити аналітичні залежності напружень у породній конструкиії від основних впливаючих факторів: величини навантаження на конструкцію, ї̈ висоти та ширини, кута внутрішнього тертя закладного матеріалу та його об'ємної щзільності. Встановлено, щзо по висоті та ширині конструкцій $з$ рядової породи напруження експоненціально зменшуються. Встановлені закономірності дозволяють для забезпечення стійкості породних конструкиій визначати величину необхідного опору на бічні стінки з врахуванням основних впливаючих факторів.
\end{abstract}

Ключові слова: засіб охорони; породна конструкиія; аналітична модель; фактори; напруження.

Актуальність теми. Зі збільшенням глибини ведення гірничих робіт в умовах вугільних шахт Донбасу все більш складною є проблема забезпечення експлуатаційного та безпечного стану підготовчих виробок, який залежить від великої кількості гірничо-геологічних та гірничотехнічних факторів. 3 метою зменшення витрат на проведення виробок, а також забезпечення високих навантажень на лави все більше уваги приділяється комбінованим системам розробки, які передбачають підтримання підготовчих виробок позаду очисних вибоїв для повторного використання та стійкого провітрювання виїмкових дільниць. В таких умовах виробка позаду лави охороняється в системі «масив-вироблений простір», тому для забезпечення її стійкості необхідне спорудження штучних охоронних споруд (литих смуг, кострів, бутових смуг, тумб БЗБТ тощо), які різняться вартістю реалізації та ефективністю.

Найменш вартісними є бутові смуги, оскільки передбачають використання рядової породи, але вони найменш ефективні внаслідок великої піддатливості. Для зменшення їх піддатливості та забезпечення достатнього опору нависаючим породам покрівлі до їх конструкцій додаються обмежуючі поверхні (автомобільні шини, металеві сітки, мішки, листовий метал тощо). Тоді порода разом з такими поверхнями може працювати як єдина, досить стійка вантажонесуча конструкція. Але не всі такі конструкції доволі ефективні, оскільки на даний момент недостатньо обгрунтовані іх раціональні параметри для певних гірничо-геологічних умов. Тому є перспективною подальша розробка або вдосконалення засобів охорони 3 рядової породи зі спеціальними конструктивними особливостями. Для цього необхідне ретельне вивчення механічних процесів та дослідження особливостей передачі навантажень у цих породних конструкціях.

Аналіз останніх досліджень та публікацій, на які спирається автор. Вивченню механічних процесів у конструкціях з рядової породи присвячено багато досліджень науковців. В них розглядалися породні опори для охорони підготовчих виробок [1-3] або управління покрівлею за умови часткового закладення виробленого простору позаду лави [4-7]. На особливу увагу заслуговує дисертаційне дослідження проф. Ю.В. Бондаренка [4], у якому визначаються параметри самозаклинювання породи під час формування опор та було теоретично обгрунтовано й експериментально підтверджено закономірності утворення зон різної несучої здатності в породних опорах за відсутності бічного опору, а також встановлено особливості їх навантаження. Вільна породна насипка складається з несучого ядра, периферійних зон та зон вільних укосів. У певних умовах насипки здатні утримувати діючі навантаження за рахунок утворення несучого ядра та периферійних зон, які замикають це ядро і протидіють його бічному розширенню [4]. У несучому ядрі частки матеріалу стискаються без центробіжних переміщень, а у периферійних зонах та зонах вільних укосів - зміщуються від ядра до країв (рис. 1). Встановлено оптимальне співвідношення ширини $B$ до висоти $h$ опори, яке дорівнює 6 і при якому забезпечується найменша величина стискуваності $42 \%$. Подальше збільшення $B / h$ не доцільне, оскільки стискуваність залишається близько 40-41 \%. Розмір несучого ядра також залежить від відношення $B / h$ і чим більше відношення, тим більше ядро. Також 
встановлено, що збільшення міцності матеріалу для спорудження опор майже не впливає на стисненість опори та розміри ядра, але крупність матеріалу впливала тільки на початковому етапі при $B / h<3$ і загальна усадка опори з матеріалів найбільшої крупності досягла $30 \%$.

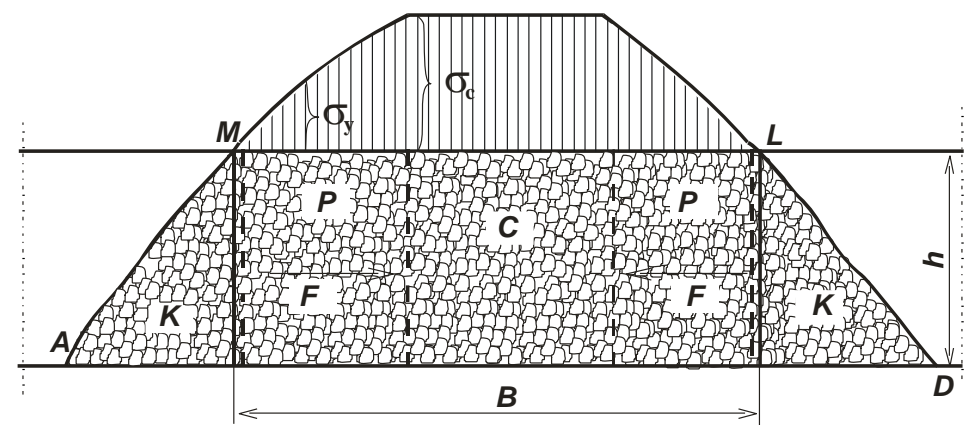

Pис. 1. Схема характерних зон вільної породної насипки AMLD [4]: C-цуентральна зона (несуче ядро); $P$ - периферійні зони; $K$-зони вільних укосів; B та $h$-відповідно висота та ширина опори; бс та бу - напруження, відповідно, у иеентральній та периферійній зонах

Отримані у [4] результати дещо пояснюють механізм навантаження та усадки породної насипки. Та, як бачимо, при вільній насипці, якою є бутова смуга у своєму поперечному перерізі, іiі усадка завелика для забезпечення стійкості виробки, що охороняється, навіть при оптимальному співвідношенні $B / h=6$. Та таке співвідношення на дуже тонких пластах може вважатися доцільним [4], але на пластах тонких та середньої потужності його не можна вважати економічно обгрунтованим, оскільки передбачається великий обсяг породи. Крім того, керівним документом [8] регламентовано, що породна смуга має бути шириною не менше ніж вісім потужностей відроблюваного вугільного пласта.

Оскільки основною несучою зоною породної насипки є центральна, а інші - допоміжні, які забезпечують рівновагу порід у першій, то цілком реальна ситуація, коли периферійні та зони вільних укосів можуть бути замінені технологічною конструкцією. В умовах слабких бічних порід важливим $є$ питання не тільки забезпечення стійкості охоронної конструкції та обмеження ії усадки, але й передача навантаження на підстилаючі породи. У результаті цього може спостерігатися просідання конструкції та покрівлі разом з нею. Передача навантаження від порід покрівлі до підошви здійснюється через область зруйнованих порід. Величина та характер деформацій навколишніх порід будуть залежати від фізикомеханічних властивостей дискретного (сипкого) середовища, яким є породна смуга.

Метою дослідження є встановлення закономірностей передачі навантажень у породних конструкціях залежно від основних фізико-механічних властивостей закладного матеріалу.

Викладення основного матеріалу. Для зруйнованого породного масиву відомі такі фізико-механічні характеристики: гранулометричний склад, щільність порід, вологість, гігроскопічність, кути природнього укосу та внутрішнього тертя, твердість часток, компресійні, когезійні та адгезійні показники, твердість часток, здатність до вібраційного ущільнення, деформаційні зсувні характеристики, коефіцієнт розподільної здатності [9]. 3 наведеного переліку, грунтуючись на дослідженнях [1-7], можна стверджувати, що найбільш впливовими на процес передачі навантажень є: гранулометричний склад, щільність та кут внутрішнього тертя порід. Встановлено, що зі збільшенням крупності фрагментів істотно зменшується ступінь передачі навантаження від фронту руйнування до контуру виробки [10], зменшення ж об’ємної маси порід у межах зони зруйнованих порід і збільшення їх в об'ємі призводить до значних зсувів контуру виробки $[11,12]$. Величина кута внутрішнього тертя порід - одна з основних характеристик сипкого середовища [9], тому необхідне ії врахування. Також не можна виключати вплив розмірів насипки, оскільки висота та ширина засобу охорони належить до чинників, що впливають на стійкість виробки. Що стосується інших показників, то одні з них $є$ менш значущі та практично не впливають на стан зруйнованих порід, а інші - істотно залежать від крупності частинок і кута внутрішнього тертя.

Механізм передачі навантаження від фронту зону зруйнованих порід від іiі фронту на кріплення виробки досліджувався у роботі проф. М.М. Касьяна [13], де на структурних моделях розглядався вплив на цей процес таких факторів, як: гранулометричний склад та розмір зони зруйнованих порід. Ступінь взаємодії між фронтом руйнування та кріпленням виробки оцінюється коефіцієнтом передачі навантаження $k_{n}[13]$, який визначався за формулою:

$$
k_{n}=\frac{q}{P}
$$

де $q$ та $p$ - навантаження, відповідно, під породною насипкою та над нею, МПа.

У продовження цього дослідження для уточнення механізму передачі навантаження від фронту руйнування було здійснене фізичне моделювання на структурних моделях [14], у результаті якого 
встановлено, що основними факторами, що впливають на цей процес, є гранулометричний склад порід, їх щільність, висота насипки та коефіцієнт внутрішнього тертя.

Усадка зруйнованих порід суттєво залежить від гранулометричного складу [15], а від усадки - їх об'ємна щільність [9]. Згідно з [15], усадка закладного породного масиву з середнім розміром кусків 0,02-0,03 м становить близько $30 \%$, а при 0,1-0,14 м - 40-50\%. Тоді об'ємна щільність $\gamma_{o}$ (т/м3), знаючи початкову насипну щільність матеріалу $\gamma_{t}$ (т/м3), для різної крупності може бути розрахована за виразом [9]:

$$
\gamma_{o}=\gamma_{H} \frac{h_{H}}{h_{H}-\Delta h_{i}},
$$

де $h_{н}$ - поточна висота породної насипки, м; $\Delta h_{i}$ - абсолютна деформація насипки при $i$-му навантаженні, м.

Тоді для закладного масиву 3 розміром кусків $0,02-0,03$ м $\gamma_{o}=1,43 \gamma_{н}$, а для $0,1-0,14$ м $\gamma_{o}=(1,67 \ldots 2,0) \gamma_{H}$. Якщо закладний масив представлений однорідним гранулометричним складом ущільнення $\gamma_{o}=(1,15 \ldots 1,2) \gamma_{H}$, а менш однорідним $-\gamma_{o}=(1,07 \ldots 1,1) \gamma_{H}[15]$. Таким чином, за рахунок зміни крупності породних фрагментів у насипці та прикладанням навантаження можна забезпечити збільшення іiї об'ємної щільності в 1,07-2,0 рази. Після того як насипка ущільнилася, гранулометричний склад на процес передачі навантаження майже не впливає, а має місце перерозподіл напружень у цілісній породній конструкції та навколо неї. Але таке ущільнення можливе за відсутності бічних деформацій та 3 жорсткою основою. На етапі ущільнення насипки передача навантаження на підстилаючі породи буде незначною, але після нього - навантаження від порід покрівлі та ваги насипки буде повністю або частково передаватися на підошву. Таким чином, фактори, які можуть впливати на передачу навантаження підстилаючим породам, будуть поєднані залежністю:

$$
q=f\left(P ; \rho_{n} ; \gamma_{o} ; h_{H} ; b_{H}\right),
$$

де $\rho_{n}$ - кут внутрішнього тертя матеріалу; $\gamma_{0}$ - об'ємна щільність матеріалу за такого навантаження, т/м³; $h_{н}$ та $b_{u}$ - відповідно поточна висота породної насипки та її ширина, м.

Напруження у породній насипці та на іiі контактах 3 примикаючими породами й обмежуючими поверхнями можуть бути визначені розв'язанням задачі граничної рівноваги елементарного об'єму одиничної ширини. Для цього можна скористатись інженерною постановкою Х.Янсена, яку широко використовують у дослідженнях напружено-деформованого стану в гірському масиві $[4,16,17]$.

Для визначення умов рівноваги елементарного об'єму (рис. 2), обмеженого контуром abcdefik, опишемо сили, що діють на нього в межах аналітичної моделі. На елементарний об'єм з боку покрівлі діє стискаюча сила: $b_{н} k_{o} \sigma_{y}$, яка обумовлює усадку зруйнованої породи (де $k_{o}-$ коефіцієнт концентрації напружень на контакті насипки та порід покрівлі), з боку підошви $-b_{H} k_{o}\left(\sigma_{y}+\left(\partial \sigma_{y} / \partial y\right) d y\right)$, вага елементарного об'єму $b_{н} \gamma_{o} \sin \alpha d y$ (де $\beta$ - кут нахилу паралельних поверхонь покрівлі та підошви насипки, град.), а також поряд зі стінками діє сила тертя $\sigma_{y} f_{c} d y$ (де $\sigma_{x}$ - бічний тиск, МПа; $f_{c}$ - коефіцієнт тертя порід по стінці).

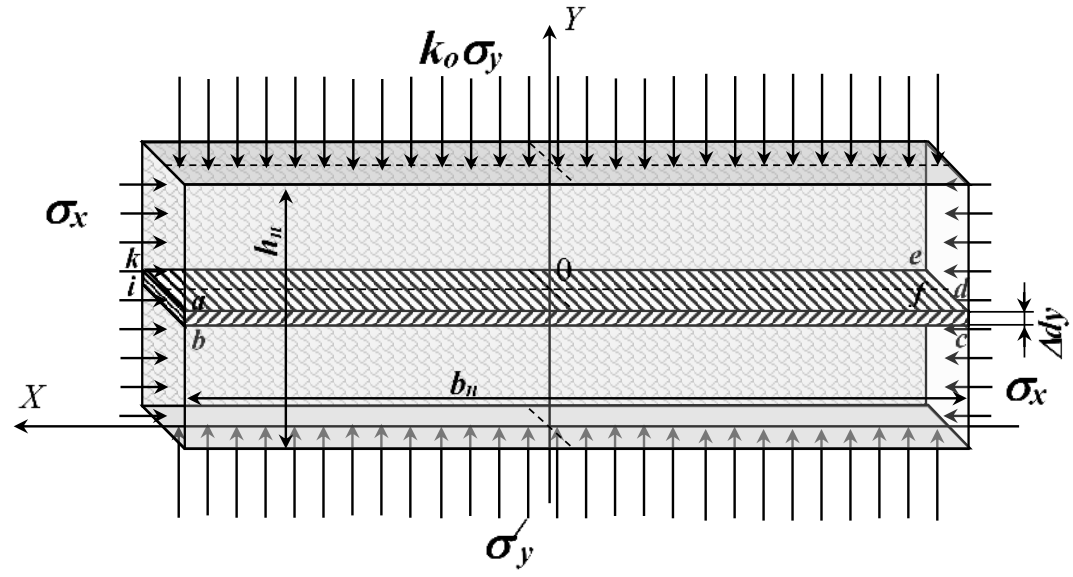

Рис. 2. Схема аналітичної моделі для складання рівняння граничної рівноваги елементарного об 'єму по висоті породної насипки з бічним опором

Диференціальне рівняння проекцій на вертикальну вісь сил, що діють на елементарний об'єм за умови граничної рівноваги, матиме вигляд:

$$
k_{o} b_{r} \sigma_{y}+b_{u} \gamma_{o} \cos \beta d y-2 \sigma_{x} f_{c} d y-k_{o} b_{u}\left(\sigma_{y}+\frac{\partial \sigma_{y}}{\partial y} d y\right)=0 .
$$


Оскільки

$$
\sigma_{x}=\lambda k_{o} \sigma_{y}
$$

де $\lambda$ - коефіцієнт бічного тиску.

$$
\lambda=\operatorname{tg}^{2}\left(45^{\circ}-\frac{\rho_{n}}{2}\right)
$$

де $\rho_{n}-$ кут внутрішнього тертя порід, град.

$$
b_{н} \gamma_{o} \cos \beta-2 \operatorname{tg}^{2}\left(45^{\circ}-\frac{\rho_{n}}{2}\right) k_{o} f_{c} \sigma_{y}-k_{o} b_{u} \frac{d \sigma_{y}}{d y}=0 \text {. }
$$

Після перетворень та вирішення цього диференціального рівняння отримаємо вираз щодо визначення напружень по висоті породної насипки з врахуванням основних впливаючих параметрів, який має вигляд:

$$
\sigma_{y}=\frac{\gamma_{o} b_{H} \cos \beta}{2 k_{o} \operatorname{tg}^{2}\left(45^{\circ}-\frac{\rho_{n}}{2}\right) f_{c}}+\left(k_{o} \gamma H-\frac{\gamma_{o} b_{H} \cos \beta}{2 k_{o} \operatorname{tg}^{2}\left(45^{\circ}-\frac{\rho_{n}}{2}\right) f_{c}}\right) e^{-\frac{2 \operatorname{tg}^{2}\left(45^{\circ}-\frac{\rho_{n}}{2}\right) f_{c}}{b_{u}} h_{\mu}} .
$$

Але у цьому виразі доданок, що характеризує вплив ваги порід у насипці за умови зміни кута її нахилу, має частку від результату $0,2 \ldots .2 \%$, тому для спрощення ним можна знехтувати. Тоді отримаємо:

$$
\sigma_{y}=k_{o} \gamma H e^{-2 \operatorname{tg}^{2}\left(45^{\circ}-\frac{\rho_{n}}{2}\right) f_{c} \frac{h_{u}}{b_{u}}} .
$$

3 отриманого виразу випливає, що від покрівлі до підошви насипки величина навантаження експоненціально зменшується (рис. 3). Такий характер зміни навантажень пояснюється дією ваги нависаючих порід покрівлі, а також зменшенням опору зруйнованих порід зі зменшенням ширини або збільшенням висоти насипки.

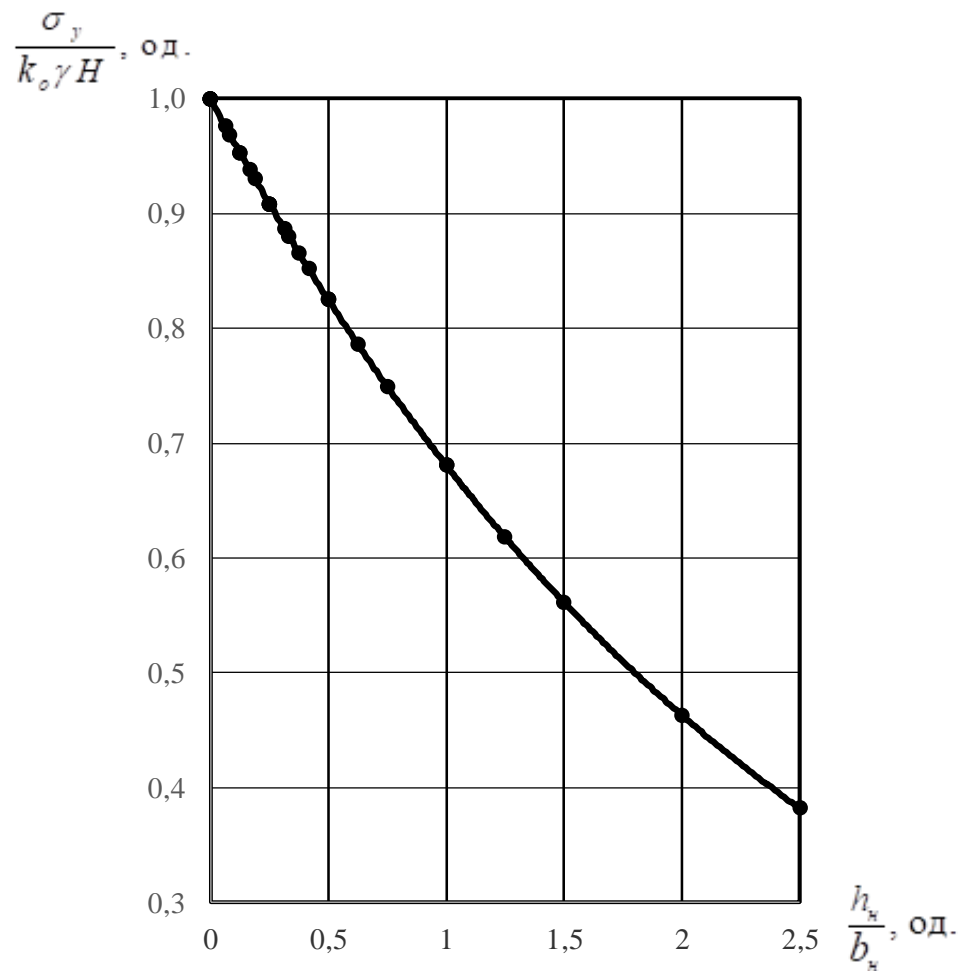

Рис. 3. Графік залежності співвідношення напружень $\frac{\sigma_{y}}{k_{o} \gamma H}$ від співвідношення геометричних розмірів насипки $\frac{h_{н}}{b_{u}}$ з бічним опором, яка знаходиться на абсолютно жорсткому шарі підстилаючих порід

Отриманий вираз показує загальну закономірність зменшення навантажень по висоті бутової смуги, але має такі допущення: вертикальний тиск на будь-якій глибині по висоті насипки приймається рівномірно розподіленим по всій площі горизонтального перетину; горизонтальний тиск у будь-якій точці 
сипучого тіла приймається пропорціональним вертикальному тиску; вплив порід підошви не враховується. Варто зауважити, що розподіл навантаження по висоті насипки за залежністю (9) при збереженні рівноваги має місце, коли бічними стінками створено достатній опір породам, які переміщуються. При зменшенні бічного опору за умови збереження рівноваги необхідно одночасно збільшувати ширину насипки, тобто збільшувати ширину периферійної зони. Це призведе до зменшення напружень поряд зі стінками, але у ядрі навантаження не зміняться. Якщо розглянути рівновагу елементарного об'єму по ширині насипки (рис. 4), то можна визначити зміни вертикальних навантажень від її стінок до центру при бічному опорі.

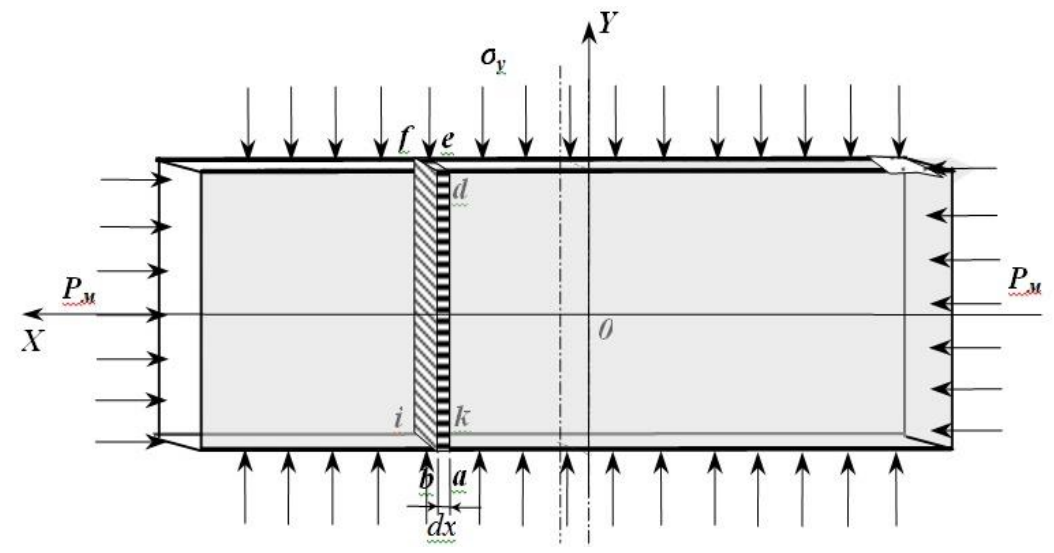

Рис. 4. Схема аналітичної моделі для складання рівняння граничної рівноваги елементарного об 'єму по ширині породної насипки з бічним опором

У цьому випадку диференціальне рівняння буде мати вигляд:

$$
h_{H}\left(\sigma_{x}+\frac{\partial \sigma_{x}}{\partial x} d x\right)+h_{\mu} \gamma_{o} \sin \beta d x-2 \sigma_{y} f d x-h_{H} \sigma_{x}=0
$$

Розв'язання цього рівняння дозволило отримати залежність вертикальних напружень, яка має вигляд:

$$
\sigma_{y}=R_{M} e^{\frac{2 f_{c}}{h_{H} g^{2}\left(45^{\circ}-\frac{\rho_{n}}{2}\right)} x}+\frac{\gamma_{o} h_{H} \sin \beta}{2 f_{c}}\left(1-e^{\frac{2 f_{c}}{h_{H} t^{2}\left(45^{\circ}-\frac{\rho_{n}}{2}\right)} x}\right),
$$

де $R_{\mathcal{M}}$ - реакція бічної стінки, МПа.

Оскільки в цьому виразі вага порід у насипці несуттєво впливає на результат, то отримаємо спрощений вираз, який буде мати вигляд:

$$
\sigma_{y}=R_{M} e^{\frac{2 f_{c}}{h_{H} t g^{2}\left(45^{0}-\frac{\rho_{n}}{2}\right)^{2}}}
$$

та при підстановці крайової умови, коли для $x=b_{t} / 2$, напруження по ширині породної смуги будуть визначатися виразом:

звідки

$$
R_{M}=k_{o} \gamma H e^{-\frac{b_{H}}{h_{H}} \frac{f_{c}}{\operatorname{tg}^{2}\left(45^{\circ}-\frac{\rho_{n}}{2}\right)}}
$$

$$
b_{H}=h_{H} \frac{\operatorname{tg}^{2}\left(45^{\circ}-\frac{\rho_{n}}{2}\right)}{f_{c}} \ln \frac{k_{o} \gamma H}{R_{\mu}} .
$$

Аналогічним чином, з виразу (12), можна встановити залежність зміни горизонтальних напружень в породній насипці, яка буде мати вигляд:

$$
\sigma_{x}=P_{M} e^{\frac{b_{H}}{h_{H}} \frac{f_{c}}{\operatorname{tg}^{2}\left(45^{\circ}-\frac{\rho_{n}}{2}\right)},}
$$

де $P_{M}-$ необхідний бічний опір переміщенню порід в насипці, МПа. 
Цей вираз показує зміну напружень у насипці в результаті докладання до неї бічного опору. Вираз (14) дозволить отримати залежність величини бічного опору від основних впливаючих чинників, яка може бути використана для встановлення параметрів охоронної конструкції з рядової породи з бічним опором, що буде здатна забезпечити рівновагу в системі «бічні породи-засіб охорони». Вона має вигляд:

$$
P_{M}=k_{o} \gamma \operatorname{Htg}^{2}\left(45^{\circ}-\frac{\rho_{n}}{2}\right) e^{-\frac{b_{H}}{h_{H}} \frac{f_{c}}{\operatorname{tg}^{2}\left(45^{\circ}-\frac{\rho_{n}}{2}\right)},}
$$

звідки

$$
b_{H}=h_{H} \frac{\operatorname{tg}^{2}\left(45^{\circ}-\frac{\rho_{n}}{2}\right)}{f_{c}} \ln \frac{k_{o} \gamma H t^{2}\left(45^{\circ}-\frac{\rho_{n}}{2}\right)}{P_{M}} .
$$

На прикладі умов пласта $c_{18}$ «Шахтоуправління «Південнодонбаське № 1 » залежність може бути представлена тривимірним графіком (рис. 5), з якого випливає, що стійкість у системі «бічні породи-засіб охорони» може бути забезпечена відносно невеликими зусиллями по краях породної конструкції 3 обмеженими геометричними розмірами.

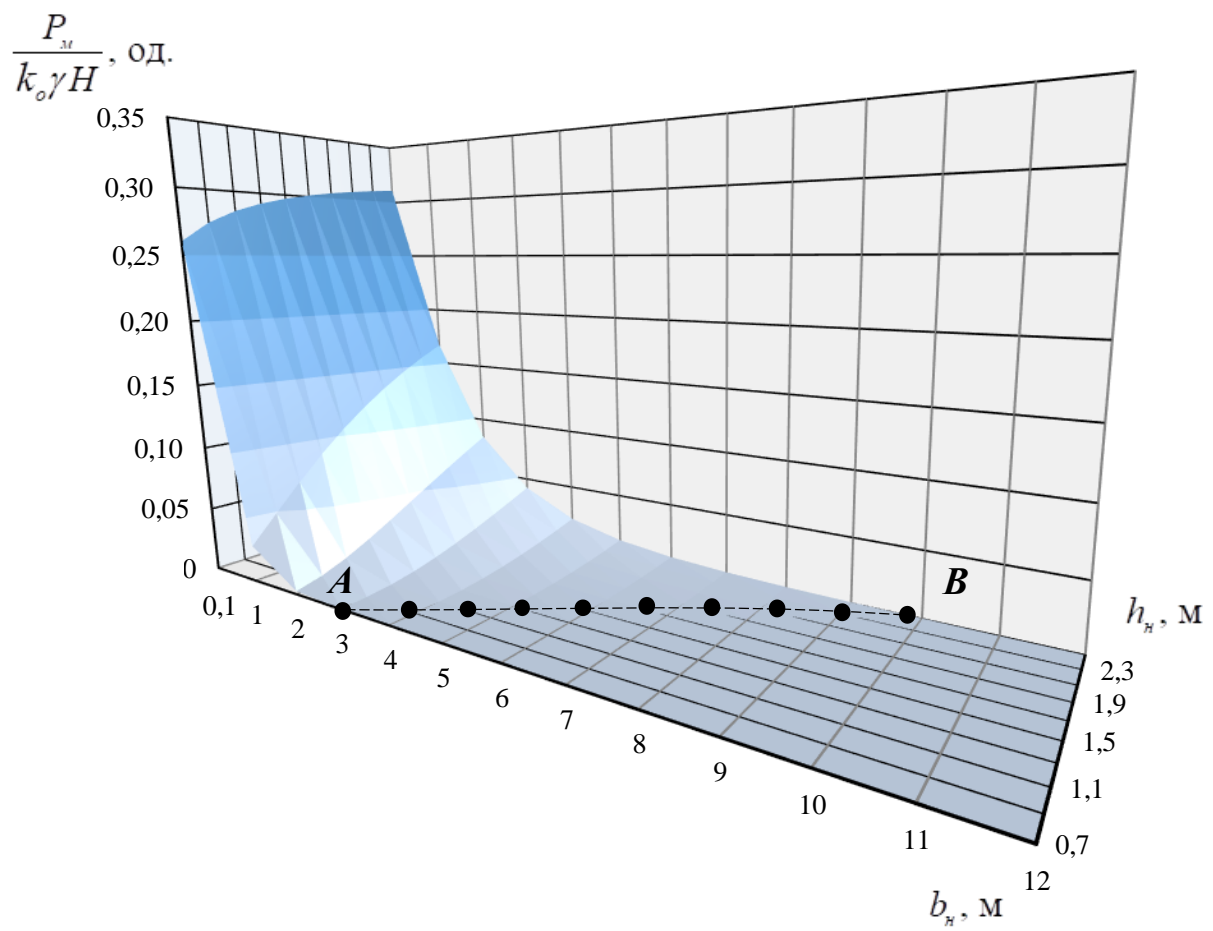

Рис. 5. Тривимірний графік залежності відносної величини необхідного бічного опору в породній насипчі

$P_{M} /\left(k_{o} \gamma H\right)$ від ї̈ ширини $b_{н}$ та висоти $h_{н}\left(\right.$ при $\left.\rho_{n}=30^{\circ}\right)$ для забезпечення рівноваги в конструкції

На рисунку 5 позначено відрізок $A B$, який показує межу, за якою напруження починають зростати. Координати точок на цьому відрізку показують граничне співвідношення ширини та висоти насипки $\left(b_{\mu} / h_{\mu}=4,0\right)$, при перевищені якого стійкість породної смуги може бути забезпечена опором іiі вільних укосів [4]. При співвідношенні $b_{\mu} / h_{H}<4,0$ необхідний бічний опір по краям породної конструкції, який може бути створений штучними опорами, що встановлюються замість периферійних зон насипок або поряд з ними. Як штучні опори можуть бути породні стійки [18]. Тобто буде споруджуватися комбінована конструкція, яка повністю складається з рядової породи, але має значно вищу несучу здатність, ніж бутова смуга.

Згідно зі встановленою залежністю, несучою здатністю охоронної споруди з рядової породи можна управляти за рахунок зміни бічного опору та ширини самої конструкції. Для збільшення ії несучої здатності ці параметри мають збільшуватись, а висота насипки зменшуватись. Висотою породної насипки у постановці, яка наведена вище, неможливо управляти, оскільки споруда має розміщуватися на всю висоту між породами покрівлі та підошви. Але можливо при зміні висоти насипки за рахунок спеціальних конструктивних рішень управляти її несучою здатністю. 
Висновки та перспективи подальших досліджень. Таким чином, досліджено особливості розподілу напружень у спорудах з рядової породи та аналітично встановлено, що по висоті (від покрівлі до підошви насипки) та ширині (від центру до країв) їх величини експоненціально зменшуються. Несуча здатність зменшується зі зменшенням ширини або збільшенням висоти й рівновага в системі «бічні породи-засіб охорони» може бути забезпечена обмеженням горизонтальних переміщень бічним опором або збільшенням сил тертя та зчеплення між породними частинками. Отримані результати дозволяють перейти до наступного етапу щодо обгрунтування параметрів обмежуючих поверхонь, які дають можливість забезпечити достатній бічний опір переміщенню порід у породній насипці з урахуванням фізикомеханічних властивостей закладного матеріалу.

\section{Список використаної літератури:}

1. Лабораторные испытания охранных сооружений с использованием породных стоек / H.H. Касьян, А.И. Ильин, В.Д. Иващенко, И.В. Хазипов // Геотехнології та управління виробництвом ХХІ сторіччя. Донецьк : ДонНТУ, 2006. - Т. 1. - С. 93-97.

2. Касьян Н.Н. Результаты лабораторных испытаний опорных породных конструкций с использованием ограничивающих поверхностей / Н.Н. Касьян, В.Л. Самойлов, И.В. Хазипов // Горный информационноаналитический бюллетень. - 2008. - № 3. - С. 240-243.

3. Ильин А.И. Шахтные специальные крепи из породных стоек / А.И. Ильин, В.М. Теросипов, С.А. Баранов // Уголь Украины. - 2003. - № 3. - С. 14-15.

4. Бондаренко Ю.В. Научные основы безлюдной и безотходной технологии выемки весьма тонких пологих пластов : дисс. ... д.т.н. : спец. 05.15.02 / Ю.В. Бондаренко. - Донецк, 1991. - 355 с.

5. Исследования силового взаимодействия свободнорасширяющихся породных опор с боковыми породами / Ю.В. Бондаренко, А.К. Носач, А.Ю. Макеев, И.В. Антипов // Разработка месторождений полезных ископаемых. - 1989. - № 84. - С. 37-39.

6. О некоторых условиях формирования опорных полос из отбитого угля при безлюдной выемке / К.Ф. Сапиикий, Ю.В. Бондаренко, Д.Д. Выговский, И.И. Гомаль // Разработка месторождений полезных ископаемых. - 1982. - № 63. - С. 72-77.

7. Способы повышения жесткости породных опор / В.Д. Иващенко, В.Н. Артамонов, И.Н. Кузык, М.В. Сердюченко // Известия высших учебных заведений. Горный журнал. - 1994. - № 3. - С. 50-52.

8. Підготовчі виробки на пологих пластах. Вибір кріплення, способів і засобів охорони : СОУ 10.1.00185790.011:2007. - К. : Мінвуглепром України, 2007. - 113 с.

9. Каталымов А.В. Дозирование сыпучих и вязких материалов / А.В. Каталымов, В.А. Любартович. - Л. : Химия, 1990. - 240 с.

10. Сучасні проблеми проведення та підтримання гірничих виробок глибоких шахт / під заг. ред. С.B. Янко. Донецьк : ДУНВГО, 2003. - 256 с.

11. Черняк И.Л. Управление массивом пород вокруг подготовительной выработки с помощью активного распора / И.Л. Черняк, А.Б. Юсов // Уголь. - 1982. - № 9. - С. 21-23.

12. Влияние плотности разрушенного породного массива на устойчивость выработки / Ю.В. Бондаренко, Г.И. Соловьев, С.Г. Негрей, Е.В. Кублиикий // Сборник научных трудов Национальной горной академии Украины. - Днепропетровск, 2001. - № 12, Т. 2. - С. 91-95.

13. Касьян М.М. Геомеханічні основи управління зоною зруйнованих порід навколо виробок для забезпечення їх стійкості на великих глибинах : автореф. дис. на здобуття наук. ступеня д.т.н. : спец. $05.15 .02 /$ М.М. Касьян. - Донецьк, 2002. - 21 с.

14. Негрій С.Г. Дослідження механізму передачі навантаження на кріплення виробки від фронту руйнування порід / С.Г. Негрій, І.Г. Сахно, В.М. Мокрієнко // Вісті Донецького гірничого інституту. - 2008. - № 2. - С. 13-18.

15. Цирель C.В. Оценка влияния гранулометрического состава на сжимаемость и пустотность закладочного материала / С.В. Цирель, Ю.С. Гапонов, А.Н. Шоков // Горный информационно-аналитический бюллетень. 2013. - № 12. - С. 80-83.

16. Гмошинский В.Г. Горное давление и расчет крепей горизонтальных выработок / В.Г. Гмошинский // Исследования горного давления. - М. : Государственное научно-техническое издательство литературы по горному делу, 1976. - С. 411-434.

17. Махно Е.Я. Вопросы разработки крутопадающих пластов угля с применением щитовой крепи / Е.Я. Махно. М. : Углетехиздат, 1957. - $230 \mathrm{c.}$

18. Патент UA. Спосіб охорони підготовчих виробок / М.М. Касьян, Е.П. Фельдман, І.В. Хазіпов, С.Г. Негрій, В.М. Мокрієнко. - 2010. - № 54012 ; Бюл. № 20.

\section{References:}

1. Kas'yan, N.N., Il'in, A.I., Ivashchenko, V.D. and Khazipov, I.V. (2006), «Laboratornye ispytaniya okhrannykh sooruzhenii s ispol'zovaniem porodnykh stoek», Geotehnologii' ta upravlinnja vyrobnyctvom HHI storichchja, DonNTU, Donec'k, Vol. 1, pp. 93-97.

2. Kas'yan, N.N., Samoilov, V.L. and Khazipov, I.V. (2008), «Rezul'taty laboratornykh ispytanii opornykh porodnykh konstruktsii s ispol'zovaniem ogranichivayushchikh poverkhnostei», Gornyi informatsionno-analiticheskii byulleten', No. 3, pp. 240-243. 
3. Il'in, A.I., Terosipov, V.M. and Baranov, S.A. (2003), «Shakhtnye spetsial'nye krepi iz porodnykh stoek», Ugol' Ukrainy, No. 3, pp. 14-15.

4. Bondarenko, Yu.V. (1991), «Nauchnye osnovy bezlyudnoi i bezotkhodnoi tekhnologii vyemki ves'ma tonkikh pologikh plastov», D.Sc. Thesis of dissertation, spets. 05.15.02, Donetsk, $355 \mathrm{p}$.

5. Bondarenko, Yu.V., Nosach, A.K., Makeev, A.Yu. and Antipov, I.V. (1989), «Issledovaniya silovogo vzaimodeistviya svobodnorasshiryayushchikhsya porodnykh opor $\mathrm{s}$ bokovymi porodami», Razrabotka mestorozhdenii poleznykh iskopaemykh, No. 84, pp. 37-39.

6. Sapitskii, K.F., Bondarenko, Yu.V., Vygovskii, D.D. and Gomal', I.I. (1982), «O nekotorykh usloviyakh formirovaniya opornykh polos iz otbitogo uglya pri bezlyudnoi vyemke», Razrabotka mestorozhdenii poleznykh iskopaemykh, No. 63, pp. 72-77.

7. Ivashchenko, V.D., Artamonov, V.N., Kuzyk, I.N. and Serdyuchenko, M.V. (1994), «Sposoby povysheniya zhestkosti porodnykh opor», Izvestiya vysshikh uchebnykh zavedenii. Gornyi zhurnal, No. 3, pp. 50-52.

8. Minvugleprom Ukrai'ny (2007), SOU 10.1.00185790.011:2007, Pidgotovchi vyrobky na pologyh plastah. Vybir kriplennja, sposobiv i zasobiv ohorony, K., 113 p.

9. Katalymov, A.V. and Lyubartovich, V.A. (1990), Dozirovanie sypuchikh i vyazkikh materialov, Khimiya, L., 240 p.

10. Suchasni problemy provedennja ta pidtrymannja girnychyh vyrobok glybokyh shaht (2003), in Janko, S.V. (ed.), DUNVGO, Donec'k, $256 \mathrm{p}$

11. Chernyak, I.L. and Yusov, A.B. (1982), «Upravlenie massivom porod vokrug podgotovitel'noi vyrabotki s pomoshch'yu aktivnogo raspora», Ugol', No. 9, pp. 21-23.

12. Bondarenko, Yu.V., Solov'ev, G.I., Negrei, S.G. and Kublitskii, E.V. (2001), «Vliyanie plotnosti razrushennogo porodnogo massiva na ustoichivost' vyrabotki», Sbornik nauchnykh trudov Natsional'noi gornoi akademii Ukrainy, Dnepropetrovsk, No. 12, Vol. 2, pp. 91-95.

13. Kas'jan, M.M. (2002), «Geomehanichni osnovy upravlinnja zonoju zrujnovanyh porid navkolo vyrobok dlja zabezpechennja i'h stijkosti na velykyh glybynah», Abstract of D.Sc. dissertation, spec. 05.15.02, Donec'k, $21 \mathrm{p}$.

14. Negrij, S.G., Sahno, I.G. and Mokrijenko, V.M. (2008), «Doslidzhennja mehanizmu peredachi navantazhennja na kriplennja vyrobky vid frontu rujnuvannja porid», Visti Donec'kogo girnychogo instytutu., No. 2, pp. 13-18.

15. Tsirel', S.V., Gaponov, Yu.S. and Shokov, A.N. (2013), «Otsenka vliyaniya granulometricheskogo sostava na szhimaemost' i pustotnost' zakladochnogo materiala», Gornyi informatsionno-analiticheskii byulleten', No. 12, pp. 80-83.

16. Gmoshinskii, V.G. (1976), «Gornoe davlenie i raschet krepei gorizontal'nykh vyrabotok», Issledovaniya gornogo davleniya, Gosudarstvennoe nauchno-tekhnicheskoe izdatel'stvo literatury po gornomu delu, M., pp. 411-434.

17. Makhno, E.Ya. (1957), Voprosy razrabotki krutopadayushchikh plastov uglya s primeneniem shchitovoi krepi, Ugletekhizdat, M., $230 \mathrm{p}$.

18. Kas'jan, M.M., Fel'dman, E.P., Hazipov, I.V., Negrij, S.G. and Mokrijenko, V.M. (2010), Sposib ohorony pidgotovchyh vyrobok, Patent UA, Bjul. No. 20, Pat. No. 54012.

Негрій Сергій Григорович - кандидат технічних наук, доцент кафедри розробки родовищ корисних копалин ДВНЗ «Донецький національний технічний університет».

Наукові інтереси:

- розробка родовищ корисних копалин;

- розробка ресурсозберігаючих технологій охорони гірничих виробок при підземному видобутку вугілля.

https://orcid.org/0000-0002-3195-8401.

E-mail: serhii.nehrii@donntu.edu.ua. 